\title{
Analysis of present IWRM in the Upper Brahmaputra and the Upper Danube River Basins
}

\author{
W.-A. Flügel and A. Bartosch \\ Department of Geoinformatics, Friedrich Schiller University Jena, Germany
}

\begin{abstract}
Integrated Water Resources Management (IWRM) is a process which strives towards the sustainable management of water resources in river basins. The approach integrates insights and knowledge from various scientific disciplines comprising natural, socio-economic, and engineering sciences. These three pillars of sustainability are important components of this approach integrating the environmental, economic and social dimension. In the ideal IWRM case planning is based on the river basin scale and therefore is comparatively discussed herein for the two twinning BRAHMATWINN river basins, i.e. the Upper Danube River Basin (UDRB) in Europe and the Upper Brahmaputra River Basin (UBRB) in South Asia. In this chapter major challenges for the implementation of the IWRM process towards a sustainable management of water resources in the two UDRB and UBRB twinning river basins of the BRAHMATWINN project are analysed. The study revealed that in the UDRB the IWRM approach is already part of water management planning and the implementation of the EU Water Framework Directive (WFD) is a good example in this regard. Contrary in the UBRB the implementation of IWRM is just at the beginning phase, only recently is being discussed in the riparian states but has not been implemented in any way so far on the basin scale.
\end{abstract}

\section{Introduction and objectives}

IWRM is understood as a continuous process of coordinating sustainable land and water resources management with the aims (1) to maximize the socio-economic development and social welfare without (2) compromising the sustainability of vital ecosystems (GWP, 2000). Thus IWRM internationally is considered as the appropriate way to implement sustainable management of river basin water resources and to adapt respective strategies to impacts of climate change (Flügel, 2010). Applied in river basins IWRM has to provide the administrative and technological means to firstly manage the sustainable use of available surface and subsurface water resources, secondly to guarantee their sustainable recharge dynamics both in terms of water quantity and quality, and thirdly to protect water users and the society against destructive flood and drought hazards.

Climate change is a major challenge for the implementation of IWRM in both twinning basins and describes the overall objective of the studies carried out in the BRAHMATWINN project. In view of these challenges the results presented herein provide a comprehensive assessment, analysis and evaluation of present IWRM practices and their adap-

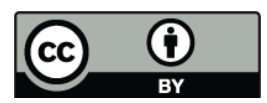

Correspondence to: W.-A. Flügel

(c5wafl@uni-jena.de) tive potential in respect to mitigate likely impacts from climate change. Focus is given on urban and industrial water demands, irrigation and hydropower, water distribution policies, water pollution and water quality issues.

\section{Role within the integrated project}

Within the context of the BRAHMATWINN project an analysis of applied IWRM strategies and practices as well as an assessment of the related institutional framework is delivering the required information and knowledge base to identify indicators with relevance for IWRM (Chapter 6), to design IWRM "what-if?" scenarios with respect to climate change (Chapter 8) and to develop appropriate IWRM adaptation strategies (Chapter 10). The study strongly elaborates on input from the assessment of the natural environment (NE) and its human dimension (HD) described in Chapter 3 and 4, respectively. Adaptation to climate change and mitigation of climate change impacts are crucial challenges in both the UDRB and the UBRB. The study is providing a analysis of existing IWRM practices and potential IWRM application as a prerequisite for the development of IWRM strategies options presented in Chapter 10. By combining the IWRM analysis results with the development of Water Resources Response Units (WRRU) a conceptual methodology is provided to analyse the spatial distribution of runoff generation as a prerequisite for improved flood management. 


\section{Scientific methods applied}

The analysis of present IWRM practices was based on expert knowledge from local project partners and the evaluation of numerous reports published in the UDRB and the UBRB respectively. Information was also derived from a comprehensive literature review including most recent publications. Focus was given on existing water governance systems in the regions, implemented water management projects, strategies to achieve stated Millennium Development Goals (MDG) (UN, 2005) and the development of river basin plans and management initiatives to generate awareness of climate change impacts. An analysis and comparison of IWRM practices in the twinning river basins of the UBRB and the UDRB was carried out based on information available from the different stakeholders and project partners. The concept of Water Resources Response Units (WRRU) is introduced and described with respect to the delineation of Hydrological Response Units (HRU) in Chapter 3. Their distribution in the UBRB with respect to regional differences of runoff generation is briefly discussed.

\section{Results achieved and deliverables provided}

The twinning UDRB and UBRB both are representative in a global perspective for trans-boundary basins having alpine mountain headwater catchments and supplying their forelands with water resources to sustain food production, socioeconomic development and the environment. In both basins millions of people depend on fresh water of high quality and sufficient quantity, and each basin experienced flood and drought hazards claiming human lives and destroying settlements and infrastructures. Investigations on climate change in both basins indicate that the risk of natural hazards might rise in the near future, and the need for adaptive water management strategies is increasingly be appreciated as a required IWRM measure.

Related to the glacier retreat in their alpine headwater catchments the UDRB and UBRB twinning basins have many consequent processes in common, which can jointly be analysed in a comparative strategic IWRM analysis:

- Runoff regimes range from glacial-nival to pluvial with snow and glacier melt driving flood hydrographs during spring till early summer and establishing base flow during summer.

- Glacier lake outburst floods (GLOFs) or floods from storm rainfall as well as summer droughts, are typical hydrological threats to the livelihoods of people and water management infrastructures.

- Thawing permafrost is increasing the risk of slope instability triggering landslides and rockfall processes and increasing the sediment load of rivers.
- Water quality is deteriorated by urban and industrial point sources as well as by non-point subsurface seepage from agricultural lands.

- Hydropower potential is high and competes with demands from other water users and the environment.

- Present climate change impacts are likely to exaggerate during the forthcoming years triggering hydrological changes that will impact present water management.

- IWRM related trans-boundary conflicts and water related disputes exist and are in part linked to national water management regulations and policies.

Besides these common challenges both basins also differ distinctively in other issues that require the regional adaptation of IWRM modelling tools provided by the BRAHMATWINN partners:

- Present climate is of an oceanic temperate type in the UDRB and monsoonal with complement pre-monsoon storm rainfall in the UBRB.

- The monitoring network is dense in the UDRB, while it is sparse in the UBRB.

- A complex, and sometimes conflicting, legal framework exists within the UDRB at the national level (national water legislation), the basin level (1994 Danube Convention), and the regional level (EU and UN ECE); whereas in the UBRB legal frameworks on all levels are not well developed.

- Trans-boundary conflicts in the UDRB are being dealt with through the regional and basin-wide legal framework, but in the geo-political sensitive UBRB disputes are still on-going and there is still a long way to go before a similar setup for conflict solution will be established.

- Socio-economic development is based on agriculture, industry, forestry, hydropower generation and tourism in the UDRB, and mainly on agriculture, forestry, hydropower generation, and mining in the UBRB.

- Impacts of climate change to the common natural environment are likely to be different regarding the human dimension and socio-economic environment in the UDRB and the UBRB, respectively.

\subsection{Urban and industrial water demands and water quality issues}

Urban, industrial, and agricultural water users and the environment generate the majority of water demand within the two twinning basins but have different weighting in each basin. Thus a comprehensive assessment of major water 
users and their water quality requirements is a focal element for the development and implementation of IWRM strategies and plans.

The population in the UDRB reaches about 11.5 Million people, while the UBRB is home for about 118 Million people, all depending on access to water resources in sufficient quantity and quality to meet their needs.

Present water supply in the UDRB can be described as well managed and secure. The per capita water consumption is about 1361 day $^{-1}$ in the German part of the UDRB and is showing a decreasing trend during the last decades. Rising water price and more efficient technologies in industrial multiuse water cycles are major reasons to be mentioned in this regard. About $95 \%$ of the potable water supply is produced from groundwater and spring water extractions. Industrial branches with intensive water demands like the semiconductor, aerospace, chemical, armaments and automobile industry have been established in the basin with concentrations in highly industrialized centres around the cities of Augsburg, Ingolstadt, Regensburg and Munich. Water in these industries is mainly used for cooling purposes and for energy generation. In the year 2001 the extracted water for industry added up to about $750 \mathrm{Miom}^{3}$. Two third of this demand was satisfied by surface water extractions (Bayerisches Landesamt für Wasserwirtschaft, 2005). A high degree of water use efficiency has been achieved by applying multiple-shift and circuit usage technologies. Because of the long term water resources expertise and sophisticated management strategies the UDRB actually has no serious IWRM problems in respect to water quantity and water supply. With the construction of the Main-Danube channel water is even transferred to the Rhine River basin to sustain water availability over there. However, as the Upper Danube River headwaters are glacier fed and the latter are likely to melt away to a large extend in the forthcoming decades impacts on the runoff regime of the river might change the present water availability and water balances impacting future IWRM.

The water supply-demand situation in the UBRB is quite different in all of the riparian states. While Tibet is characterized by a sparse population and respectively low water demands, Bhutan shows high potential of hydropower production for the Indian market and increasing demand for irrigation supply. Assam has the highest population and a high population density in the flood prone regions of the Brahmaputra flood plain. Water demand is high comprising public water supply and irrigation agriculture. Present water supply is facing various challenges and insufficient water treatment is causing pollution of surface and subsurface water resources. India's sanitation record is extremely poor and according to the United Nations Human Development Report (UNDP, 2006) only 33\% of India's population has access to improved sanitation facilities.

\subsection{Water distribution policies in respect to floods and droughts}

IWRM in a trans-boundary river system has to account for different policy and governance aspects relevant in the transboundary context to cope with natural hazards, i.e. landslides, GLOFs, floods and droughts. Fresh water demand from user groups in the forelands have to be satisfied in sufficient quantity and quality. Both twinning basins are characterized by seasonal runoff but in the UDRB dams and reservoirs buffer the seasonal variation of water availability and establish sufficient base flow during the year. In the UBRB such infrastructures are missing and consequently during low flow water demands for the public, industry, and the environment cannot always be met. In flood periods, however, inundation and bank erosion cause serious problems and poses risks for human livelihoods, socio-economic development and existing infrastructures.

IWRM in the UDRB is mainly based on bilateral agreements and is embedded into the regional co-operation of the Danube countries within the framework of the IHP UNESCO. The process was further driven by the implementation of the European Water Framework Directive (WFD) in 2000 and the consequent establishment of the International Commission for the Protection of the Danube River (ICPDR). The ICPDR acts as an umbrella body that is linked to the UNDP and receives scientific advice from six associated expert groups, e.g. on floods, river management or ecology (ICPDR, 2005, 2007). Water resources management in the UDRB is complex and distributes across regional, provincial, national and international scales involving bordering countries, GOs, NGOs and stakeholder groups representing urban and rural development, industries, and the environment.

The overall aim of IWRM in the UDRB is to manage flood protection, hydropower generation and water allocation by means of runoff regulation in all major tributaries and in the reservoirs located in the Alps according to the snow and glacier melt dynamics. However, in spite of the many infrastructures built in the last 100 years in the UDRB floods are still a significant risk. They mostly occur in summer time when snow- and glacier melt coincides with extreme precipitation events. With the completion of the MainDanube-Canal in 1992 the upper course of the Danube River improve the river's water balance considerably linking the UDRB draining to the Black Sea in the East with the Rhine River Basin draining towards the Northern Sea. Controversial discussed regarding its ecological impact till today the canal transfers water from the Danube to the Main thereby improving (i) the water quality during low flow, (ii) compensates for evaporation losses caused by the operation of the thermal power stations, and (iii) cuts down the number of floods in the valley of the middle Altmühl River in summer. Another significant IWRM measure is the implementation of an effective flood warning system jointly managed by the Bavarian and the Baden-Wuerttemberg Environment 
Agencies in Germany. Risk management, protection forecasting systems and public information were driven in the tributary Inn River by the cooperation between the Bavarian "Hochwassernachrichtendienst" in Germany and the Austrian "Hydrographischer Dienst" (ICPDR, 2007).

The Himalayan region of the UBRB is quite sensitive to climate change and the projected warming in Tibet is increasing faster than anywhere else in the world (IPCC, 2007). Consequently snow and glacier covered regions are at risk to melt away and will not fulfil their present water storing function in the near future which at present buffers the seasonal rainfall variation and secures the water supply in the downstream forelands. Despite the urgent need to account for climate change impacts when developing water management activities, the governments in the riparian states of the UBRB have just recently attended to these challenges.

In Bhutan the National Environment Commission is a high level autonomous agency responsible for environmental policy. It is also responsible for monitoring the impact of socioeconomic development on the environment and puts in place necessary controls and regulations for water resources and environment protection. Several hydropower projects have been implemented in the past decades to exploit the high hydropower potential of the Himalayan Mountains in Bhutan and to achieve the political objective of "electricity for all" by 2020 . Related to this development several projects have been implemented in this regard to protect water resources. For example, the Wang River in Bhutan has been exploited for hydroelectricity to improve the sustainable management of the water resources within the basin and the Wang Watershed Management Project (WWMP) has been initiated in 2002.

Within India there are numerous government agencies involved in managing the various inter-related IWRM aspects of the Brahmaputra system including the pressing issues of protecting against flood inundation and associated bank erosion. With $40 \%$ of its land surface susceptible to flood damage, the Brahmaputra valley represents one of the most hazard-prone regions in India, having a total flood prone area of 3.2 million hectares (Das, 2005). However, still today there is no effective mechanism in place to coordinate interlinked IWRM activities undertaken by these agencies. In many cases IWRM became a casualty in letter and spirit as can be seen for example by reservoirs built for hydropower by the North Eastern Electric Power Corporation Limited (NEEPCO) without integrating obvious demands for flood control and irrigation water supply. Flood protection management by means of rainfall and snow melt based predictive runoff modelling and the integration of natural wetland flood retention in the NE-Indian flood plains is not implemented so far and needs special attention when striving towards IWRM and integrated flood management.

Trans-boundary IWRM in the UBRB also relates to the sensitive geo-political situation with on-going territorial disputes between the riparian states. Present water management therefore is mainly based on state and national regulations and co-operation between riparian countries is still in the initial phase, demanding further improvement. Nevertheless, agreements at the trans-boundary level already exist, for example between India and Bhutan related to joint hydropower production.

Because of the unresolved water resources issues meteorological and discharge data are mostly classified and were not made accessible for joint IWRM initiatives to neighbouring countries. Encouraging initiatives for improvements are the agreement between the Government of India and the People's Republic of China for the sharing of hydrological information of the Brahmaputra River during the monsoon flood season. Based on this agreement hydrological information, i.e. water level, discharge and rainfall from the three Tibetan stations Nugesha, Yangcun and Nuxia located at the Yarlung Tsangpo is provided to India from 1 June to 15 October every year (National Portal of India, 2010). However, other conflicts remain unresolved such as the construction of huge hydropower dams in China and India that are located in the earth-quake prone Himalaya region of the UBRB or water transfer plans related to the National River Linking Project (NRLP) of India (Jain et al., 2008).

\subsection{Water consumers and polluters}

In headwater and upstream river ranges water quality in general is quite good, but deteriorates downstream as they receive waste water inflows from point and non-point sources. Especially densely populated areas and such with high industrial activity contribute significantly to the pollution of surface and subsurface water resources.

In the UDRB water quality is basically in good condition. Waste water treatment is common practice and effluences into the river are strictly regularized and controlled. As a consequence countries downstream of the UDRB receive good water quality by the Danube River. The ICPDR is responsible for the implementation of the EU water framework directive and as a superior authority attempts to establish good water quality and sufficient water availability for downstream water users. Water quality risks are caused by diffuse pollution sources from the agricultural sector in form of fertilizers and pesticides as well as from hazards from suddenly spilling poisoning waste waters into the river as it has happened twice in Hungary during the last decade.

In the UBRB waste water discharge into the river is a common practice and is not regularly monitored by the authorities. The river consequently suffers from a declining water quality and especially the north-eastern Indian states have to cope with polluted surface- and groundwater resources. Missing waste water treatment and insufficient waste disposal are major IWRM challenges with respect to water quality in these regions as they are in India in general. Most rural settlements and even large cities as Guwahati are not sufficiently connected to waste water treatment systems 
and untreated sewage flows into rivers polluting surface and groundwater bodies. Waste water is also used for irrigation posing considerable risks to both irrigators and consumers. Uncontrolled solid waste disposal is even exaggerating the situation and contributes to the environment pollution that is obvious in many riparian states of the UBRB.

\subsection{Irrigation agriculture, fertilization and crop pattern}

In the UBRB water use for irrigation agriculture accounts for about $70-80 \%$ of the total water consumption. Agriculture is an important employer providing jobs to some $80 \%$ of the Bhutanese population although only $12.5 \%$ of the arable land (7\% of Bhutan's state area) is under irrigation. Traditional irrigation is dominant with well-known inefficiencies, i.e. high water losses by evapotranspiration. Water management needs to focus on improving water supply to the irrigated areas, especially in times of water shortage. Because of shortfalls in irrigated rice production today some $50 \%$ of the rice consumed in Bhutan has to be imported from India. Hence increasing of self-sufficiency has high priority and the Government of Bhutan, and the Ministry of Agriculture $(\mathrm{MoA})$ policies have recently stressed the need to widen the crop pattern that are grown under irrigation, and to introduce new forms of modern micro irrigation techniques for more efficient farm management.

The governance system consists of formal and informal institutions and organizations complemented by public and local farmer associations that generate the frame for an effective agricultural water management. Irrigation management in most parts of the UBRB is a matter of local governments and farmers associations. In Bhutan for example the latter control most of the irrigation schemes through Water User's Associations (WUAs), and only two larger schemes in the south are managed by the local government. Water use for irrigation is bound by the National Irrigation Policy of Bhutan, and essential components of this policy include the establishment and integrated participation of water user groups and the operation and management of the irrigation schemes by farmer associations with only a supportive role played by the Government of Bhutan.

In India/Assam there is an urgent need to improve the agricultural production from its current level to meet the demands from the ever growing population. Existent irrigation schemes in Assam had been designed as river diversion run-of-the-river-schemes, hence irrigation water is not always readily available at the time of need. There is not a single storage type irrigation system which could buffer flood surplus to support low flow by provide the required storage capacity to significantly increase cropping intensity and crop productivity to higher levels. The Ministry of Water Resources is responsible for the monitoring and technical guidance of the irrigation schemes and the Department of Irrigation in Assam is responsible to improve the situation based on a step wise irrigation development program.

\subsection{Groundwater resources, quality and exploitation}

Groundwater use in Assam, India, is suffering from constraints due to bad water quality resulting either from natural bedrock sources, from solid water disposals or agricultural fertilizer, herbicide and pesticide applications. If groundwater is suitable it is often overexploited and in Assam both processes are frequently combined. Demand driven development of ground water resources by different user groups is dominant and little or no management strategies based on proper understanding of local ground water regimes is applied leading to progressing depletion of the resources and degradation of groundwater quality.

A literature review reveals that groundwater resources in Assam are highly ferruginous and often have high fluoride and arsenic contents. As a consequence of uncontrolled use of such groundwater fluorosis is of public concern and has been widely reported. The situation of the water quality in the region and continuous consumption of contaminated groundwater is alarming and poses serious health hazard to the local population. This unfavourable situation is aggravated by input from agriculture due to inappropriate application of fertilizers, pesticides and herbicides which can seep into the groundwater aquifer and move towards the groundwater wells.

The Central Ground Water Board carries out regional hydro-geological studies which provide information on ground water occurrence in different terrains and are essential for sustainable future planning of ground water development and management. One headquarter is located in Guwahati and is responsible for the groundwater management in the North Eastern Region (NER) of India. Because of the hydro-geological situation common to all states in the NER it is a must for such state authorities to jointly establish a common IWRM platform to address all issues related to surface and subsurface water resources management by applying an integrated and holistic systems approach supported by respective assessment and management decision methodologies.

\subsection{IWRM enhancement of the $\mathrm{RU}$ regionalization approach}

For improving flood management the Water Resources Response Units (WRRU) approach was developed, which basically identifies areas with a high runoff contribution that generate floods. Basis for the delineation of WRRU are the Hydrological Response Units (HRUs) introduced in Chapter 3. HRUs are defined as distributed spatial model entities which have a similar hydrological process dynamics and therefore generate similar outputs as response to a given rainfall input (Flügel, 1995). The hydrological system analysis is providing the definition of process based criteria to delineate HRUs by means of GIS analysis which represent distributed landscape entities of unique hydrological system response. The 


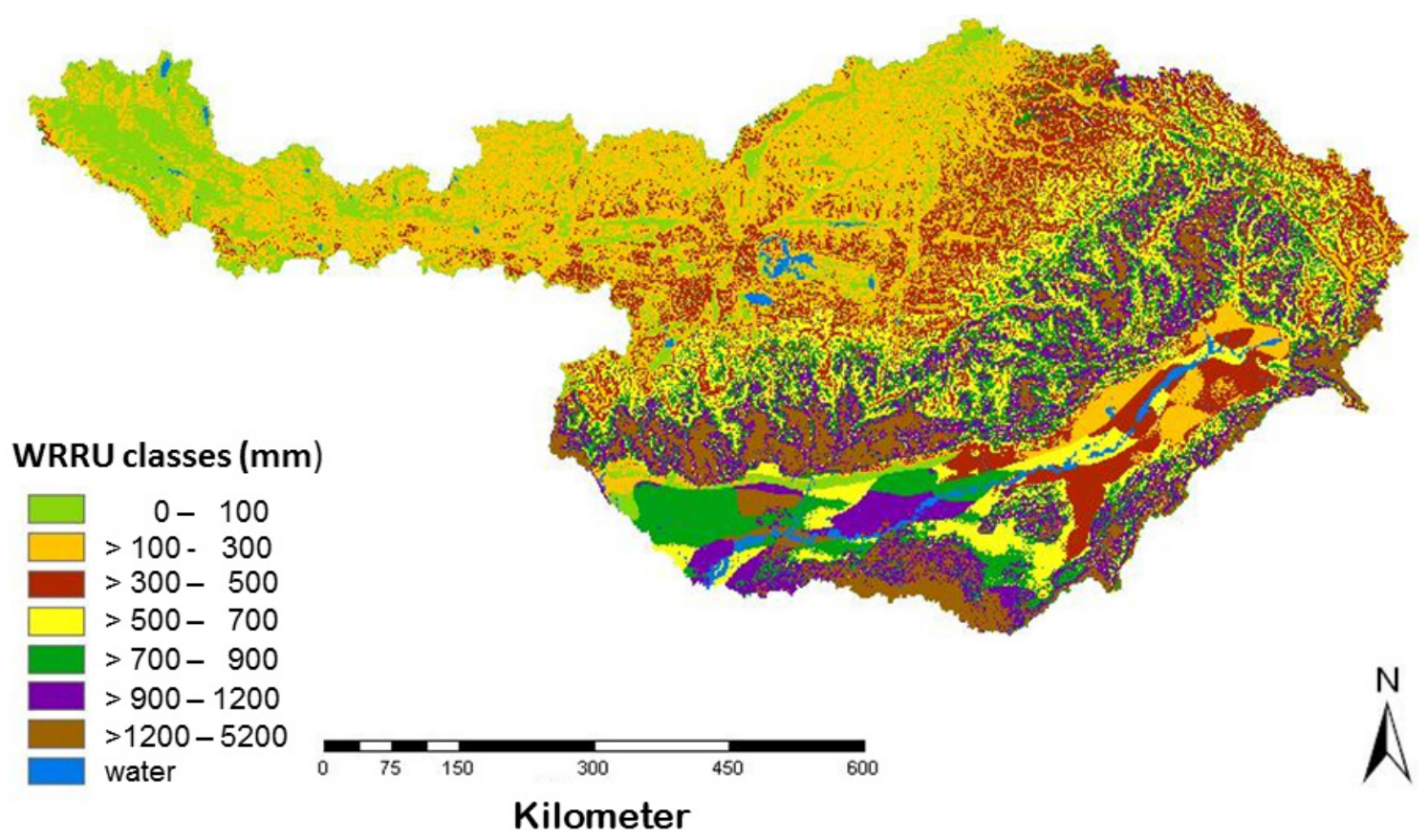

Figure 1. Water Resources Response Units (WRRU) distributed within the UBRB.

application of the RU conceptual landscape model offers substantial progress for a hydrological and process oriented water balance analysis in river basins.

The mean annual water balance components obtained from the hydrological modelling done by means of the DANUBIA hydrological model (Chapter 7) were used as inputs for the delineation of the WRRUs. By classifying HRU with respect to discharge generation by surface runoff and interflow on the one side and groundwater recharge on the other WRRU are generated. In result each WRRU class is merging dominant water balance components from their different HRU components with the respective land use and land cover (LULC), topography, and soil attributes of the HRU. Depending on the in-depth GIS analysis the elaborated results will achieve different degree of detail and quantification.

The WRRU have been delineated based on the annual average of the DANUBIA modelling period 1960 till 2000 and are shown in Fig. 1.

The distribution of WRRU indicating the distributed runoff generation reveals the following results with respect to flood generation:

1. The barrier function of the Himalaya mountain ridge for the monsoon rainfall is obvious and influences the runoff generation in luv and lee of the mountain ridge.

2. The western part of the Yarlung Tsangpo (name of the Brahmaputra River in Tibet) with a semi-arid cold temperate climate has no or only little annual runoff contri- bution mostly not exceeding $200 \mathrm{~mm}$ as annual sum or $6.341 \mathrm{~s}^{-1} \mathrm{~km}^{-2}$.

3. In the middle part moderate runoff generation is dominant ranging between 300 and $500 \mathrm{~mm}\left(9.511 \mathrm{~s}^{-1} \mathrm{~km}^{-2}\right.$ till $15.851 \mathrm{~s}^{-1} \mathrm{~km}^{-2}$ ) in the middle mountain range and in insular places of the alpine ridge even reaching up to $900 \mathrm{~mm}$ or $28.541 \mathrm{~s}^{-1} \mathrm{~km}^{-2}$.

4. The main runoff generation, however, is occurring in the luv side of the Himalayan in the Nort-East Region (NER) states of India and by heavy monsoon rain in the floodplains of the rivers like the Brahmaputra ranging between $700 \mathrm{~mm}$ till $5200 \mathrm{~mm}\left(22.201 \mathrm{~s}^{-1} \mathrm{~km}^{-2}\right.$ till $164.891 \mathrm{~s}^{-1} \mathrm{~km}^{-2}$ ).

\section{Contributions to sustainable IWRM}

The detailed analysis of present IWRM practices and strategies reveals their potential to cope with impacts from climate change. Adaptation to climate change is a high priority challenge in the UBRB, which is characterized by high climate variations impacting human life, infrastructures and the environment. Assam for example has to cope with serious IWRM problems like floods, droughts and bank erosion but still lacks the appreciation to employ the required knowledge and allocate respective budgets to bring the appropriate measures in place. The analysis of present IWRM practices in the twinning basins UDRB and UBRB is a prerequisite to understand likely impacts from climate change on water management and allows the development of appropriate adaptation 
measures for mitigation. The identification of areas with high runoff generation by using the WRRU approach provides the means for effective implementation of protective or mitigating measures with respect to flood generation and forecast. The study on IWRM practices constitutes the basis for developed IWRM options, described in Chapter 10.

\section{Conclusions and recommendations}

The entire UBRB is characterized by increasing pressure on the available water and land resources due to competing water demands from different user groups, e.g. domestic consumption, agriculture, industry, tourism and recreation, hydropower, navigation and settlements. Rapid population growth in Assam, Bhutan and Tibet has been identified as a major challenge with respect to sustainable IWRM and preservation of the environment. Continuous population increase, the finite extent to which further land can be converted into agricultural use and limited water availability are serious constraints with respect to the supply of water for irrigation and are of major concern. Such constraints are already obvious in the foothills and valleys of Bhutan and Tibet. The increasing need for water and the decrease in water availability are high priority challenges for IWRM in this basin and different attempts have already be initiated to better the situation.

The Bhutan Water Policy for example puts high priority to the supply of drinking water, and the fundamental right of every individual to access good quality water. This will drive Bhutan's commitment to meet the MDG targets and underlines the importance of efficient water use and proper wastewater management. It furthermore highlights the importance of water resources protection by means of the "polluter pays" principle which is also considered in IWRM planning done in China/Tibet and India/Assam.

Although river basin commissions for the largest river basins have been implemented in China no such commission has been established so far for the Yarlung Tsangpo as the Brahmaputra is named in Tibet. Management of water resources and water supply in this part of the UBRB has to improve considerable. Water pollution is a minor concern for IWRM in Tibet but indicators show that this will become soon a matter of future concern as decreasing water quality is already apparent in various places due to uncontrolled disposal of solid wastes and insufficient treatment of waste water discharging from various sources.

With regards to the problem of flood management and respective land management options, a high priority problem in Assam, the concept of WRRU has been developed. Enhancing the RU concept toward WRRU permits to relate flood vulnerabilities to spatially distributed runoff generation and groundwater recharge dynamics on the macro-scale of the UBRB. Calculating the individual runoff generation of each WRRU class will provide water and land managers with the means to link the natural landscape environment, e.g. LULC, soil, geology and climate with the water yield produced from each geo-referenced WRRU entity. The WRRU concept thereby provides the Geoinformatics means for a coordinated land and water management in IWRM and the assessment of climate change impact on river basin water balances.

IWRM in the UBRB at present is also restricted due to state border disputes, i.e. between China and India. The activities carried out at upstream areas are both challenges, i.e. soil erosion, landslides, and deforestation as well as IWRM opportunities, i.e. provision of reliable amounts of good quality water to downstream user communities and irrigation schemes.

Acknowledgements. The cooperation and support from all BRAHMATWINN partners and stakeholders was highly appreciated and is acknowledged hereby. Acknowledgement is also given to the EC which funded the IWRMS development in the BRAHMATWINN project under the contract number 036952.

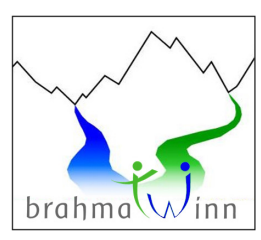

The interdisciplinary BRAHMATWINN EC-project carried out between 2006-2009 by European and Asian research teams in the UDRB and in the UBRB enhanced capacities and supported the implementation of sustainable Integrated Land and Water Resources Management (ILWRM).

\section{References}

Bayerisches Landesamt für Wasserwirtschaft: Bericht zur Bestandsaufnahme gemäß Art. 5, Anhang II, sowie Art. 6, Anhang IV, der WRRL für das Deutsche Donaugebiet, München, 2005.

Das, P. J.: Integrated Water Resources Management (IWRM): A Northeast Indian Perspective, 2005.

Flügel, W.-A.: Climate impact analysis for IWRM in Man-made landscapes: Applications for Geoinformatics in Africa and $\mathrm{Eu}-$ rope, Initiativen zum Umweltschutz, Bd. 79, 101-134, 2010.

Flügel, W.-A.: Delineating Hydrological Response Units (HRU's) by GIS analysis for regional hydrological modelling using PRMS/MMS in the drainage basin of the River Bröl, Germany, Hydrol. Process., 9, 423-436, 1995.

GWP TAC: Background Paper No. 4, Integrated Water Resources Management, Global Water Partnership, Stockholm, Sweden, 2000 .

International Commission for the Protection of the Danube River (ICPDR): Development of the Danube River Basin District Management Plan - Strategy for coordination in a large international river basin, 2005.

International Commission for the Protection of the Danube River (ICPDR): Germany facts and figures, http://www.icpdr.org (last access: 27 March 2011), 2007.

IPCC: Climate Change 2007: Synthesis Report, Contribution of Working Groups I, II and III to the Fourth Assessment Report of the Intergovernmental Panel on Climate Change (Core Writing Team, Pachauri, R. K. and Reisinger, A. (Eds.)), IPCC, 2007. 
Jain, S. K., Kumar, V., and Panigrahy, N.: Some issues on interlinking of rivers in India, Curr. Sci. India, 95, 6, 728-735, 2008.

National Portal of India: International Cooperation: http:// india.gov.in/sectors/water_resources/international_corp.php (last access: 28 March 2011), 2010.

UN: The Millennium Development Goals Report, New York, 2005. UNDP: Human Development Report 2006, New York, 2006. 